\title{
Two Cheers for Corporatism, One for the Market: Industrial Relations, Wage Moderation and Job Growth in the Netherlands
}

\section{Jelle Visser}

\author{
Article by an MPIfG researcher \\ Jelle Visser: Two Cheers for Corporatism, One for the Market: Industrial Relations, Wage Moderation and Job Growth in the \\ Netherlands. In: British Journal of Industrial Relations 36(2), 269-292 (1998). Wiley-Blackwell \\ The original publication is available at the publisher's web site: http://dx.doi.org/10.1111/1467-8543.00092
}

\begin{abstract}
The success of economic policies in the Netherlands with regard to enhancing job growth and bringing down unemployment has attracted international attention, especially against the background of persistent high unemployment in many continental European countries. The paper considers the role of Dutch industrial relations, and in particular trade unions, in the turnaround from the 'Dutch disease' to the current 'employment miracle'. It is argued that Dutch unions, weakened by the severe jobs and membership crisis of the early 1980s but assured of continued institutional support, have chosen a publicregarding 'jobs before wages' strategy. The two main features are continued wage moderation and negotiated flexibility of working hours, particularly part-time jobs. The paper stresses the importance of co-ordination within the unions as well as between unions and employers, and compares the contents, causes and consequences of the two central accords of 1982 and 1993. Finally, it considers the renewal of Dutch corporatism in an environment of increased market pressure.
\end{abstract}

\section{Introduction}

Ten years ago, Swedish sociologist Göran Therborn, in his book Why Some People Are More Unemployed than Others (1986), dubbed the Netherlands 'perhaps the most spectacular employment failure in the advanced capitalist world'. In the early 1980s unemployment in that country had reached a record number of $800,000,13$ per cent of the labour force. An almost equal number of workers had been eased out of the labour market through disability benefits and early retirement. Broad unemployment, which also counts the registered unemployed who are unavailable for work, benefi-

Jelle Visser is at the Max Planck Institute for the Study of Societies, Cologne, and the Department of Sociology, University of Amsterdam. 
ciaries of disability pensions, early retirement, people on social assistance and workers in government-sponsored training schemes and in public labour pools, had soared to 28 per cent of the labour force (OECD 1994). The Netherlands was a prime example of Gøsta Esping-Anderson's pathology of 'welfare without work', which in his view characterizes the continental European welfare states. Foreign observers chastized Dutch policies, in particular with respect to their 'keeping more than a million people supported by the welfare state', as 'cloudy and lacking in realism' (The Economist, 30 January 1982). The expression 'Dutch disease' made its appearance in economics textbooks as an example of expensive public welfare policies.

In the mid- to late 1990s, Dutch policies are again drawing international attention. Foreigners are discovering a 'Dutch miracle' (Jean-Claude Trichet of the French Central Bank, in Le Monde, 23 January 1997), 'Our Big Little Neighbour' (Institut der Deutschen Wirtschaft, 25 July 1996), a 'model' for unions and employers at home (Belgian Employment Minister Miep De Smet in De Standaard of 11 October 1996). These and other commentaries highlight the extraordinary rate of job creation, the successful approach of the EMU convergence criteria, the sustained policy of wage moderation, the lack of social unrest and the consensual style of policy-making.

In this paper I want to explain the changes that have occurred in Dutch labour market policies and outcomes with the help of industrial relations variables - conceived in a wide sense of not only union-management relations and the regulation of wages and conditions, but also public policies and the institutional framework within which labour market parties interact. I shall argue that the co-ordinated nature of union-employer bargaining relations has been instrumental in the changes that have taken place. Dutch industrial relations passed from a phase of 'immobile' to 'responsive corporatism' (Hemerijck 1995), when the labour market parties, in particular the unions, adopted a jobs-before-incomes policy. It is argued that a sharp sense of crisis and vulnerability led to the choice of wage moderation as the dominant union strategy which, together with welfare reform and activating labour market policies, helped to break the pathology of welfare without work.

In the next section I sketch the labour market developments in the past fifteen years. I then outline, briefly, the three main policies of wage moderation, welfare reform and job creation. In Section 4 I provide the main characteristics of the Dutch industrial relations system. In the fifth section I move on to discuss wage moderation, its implementation and consequences. In the final section I try to explain what caused the renewal of Dutch corporatism.

\section{Labour market performance}

In the past ten years 1 million jobs have been added to the 5 million that existed in the Netherlands in 1985. The employment ratio rose from 52 per

(C) Blackwell Publishers Ltd/London School of Economics 1998. 
cent in 1985 to 64 per cent in 1995 . The job creation rate averaged 1.8 per cent per year, against 1.5 per cent in the USA and 0.4 per cent in the EU. The strong recovery, especially in labour market terms, after the 1992-4 recession contrasts sharply with the struggling economies of Belgium, France and Germany (OECD 1997: 14).

The Dutch 'jobs machine' is based on an expansion of part-time employment. Nine out of ten recently created jobs are part-time, defined as jobs with an average working week of between 12 and 36 hours. The share of part-time work in total employment has surged from an already high 22 per cent in 1985 to 36 per cent in 1996, the highest share in the OECD by far. Of all part-time jobs, 73 per cent are held by women. The expansion of parttime work has helped to accommodate the growing supply of female labour against a background of historically low participation rates of (married) women and a reversal of the social norm concerning the paid work of women. In 1983 the Netherlands labour market still had one of the lowest female participation rates, comparable with that in Ireland, Spain and Italy. Since 1983, however, labour force participation among women has risen from 35 to 53 per cent, the strongest rise in the OECD. Of all jobs held by women, 63 per cent are part-time. Among men, the incidence of part-time work has risen to 17 per cent, also high by international comparison (CBS 1996).

Unemployment has decreased much more slowly. At 1.5 per cent per year on average, the Dutch labour force in the past decade has grown much more rapidly than that of other EU countries. Most new jobs have been taken by young entrants and women (re-)entering the labour force. For example, of the 700,000 additional jobs created between 1984 and 1990, only about 100,000 went to people on benefits (van Wijnbergen 1996).

Comparison of unemployment over time is difficult because of changes in the statistics. In 1987, about one-third of those receiving unemployment benefits were found to be unavailable for a job of at least 12 hours per week and were removed from the official count. Using the standardized unemployment rate of the OECD, which counts the unemployed who are available for work and seek a job, we observe a decrease from 12 per cent during the worst of the 1983 recession to 7.6 per cent in the recession of 1994 , and a further fall to 5.6 per cent in the last quarter of 1996, the lowest level since 1980 (see Figure 1).

Like most EU countries, the Netherlands has a severe problem of longterm unemployment (Layard et al. 1991). Since 1984, the proportion of unemployed who have been out of a job for one year or longer has been 50 per cent or more. Long-term employment started to decline only in 1996, possibly as a result of more active labour market policies (see below) and because a higher proportion of the unemployed reached retirement age. A large number of people who were laid off in the 1980-3 slump never found their way back into a paid job.

Unlike the United States, the biggest risk is not becoming unemployed when holding a job, but staying unemployed once a job is lost. In 1992, 


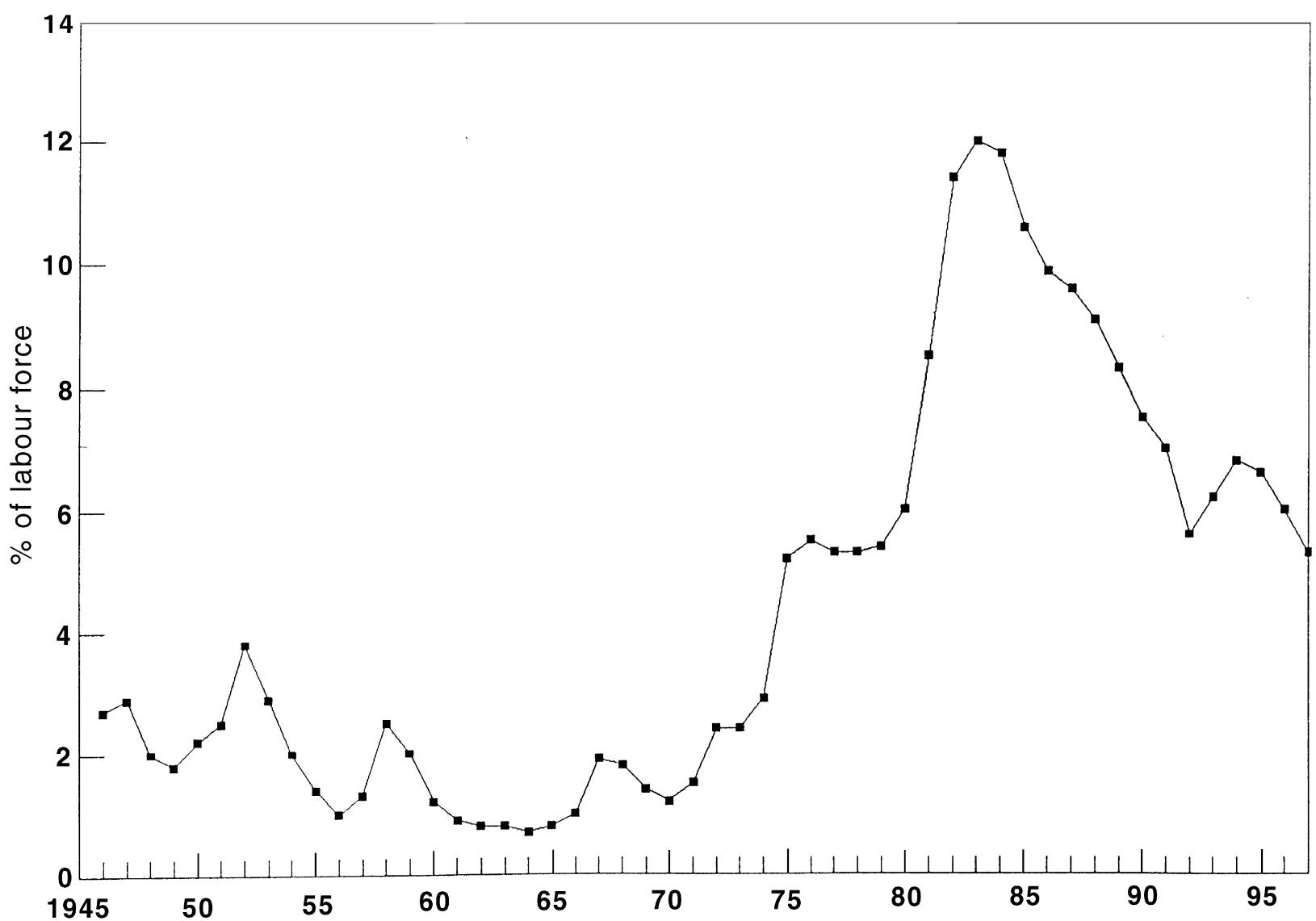


although the Dutch unemployment rate (6.7 per cent) was marginally lower than in the USA (7.3 per cent), this reflected quite different realities. In the USA about 2 per cent of all workers lost their job, each month, whereas in the Netherlands the figure was just 0.5 per cent. In the USA, however, 40 per cent of the unemployed found new jobs within a month, against only 5-6 per cent in the Netherlands (OECD 1993: table 3.3). Between 1977 and 1990, the average length of (uncompleted) unemployment spells has increased in the Netherlands by a factor of three (de Beer 1996: 95). This figure, resulting from a combination of employer selection, a lack of (re- )training opportunities and, possibly, a lack of incentives to leave social security, suggests severe inefficiencies and inequality of opportunity in the Dutch labour market, notwithstanding the overall improvement in economic performance.

Unemployment in the Netherlands is concentrated among the low-skilled and has a racial aspect (Salverda 1996). Unemployment among workers with only eight years of education is twice the national average, and among nonnative workers it is three times the average. The problem appears to have become greater rather than smaller; jobs requiring only elementary or basic vocational training are disappearing and most new jobs require longer schooling.

The reform of the disability pension system in 1993, intended to stop the rising number of claimants, has added to the plight of the older unskilled worker. Between 1980 and 1990 the number of workers receiving disablement pensions nearly doubled, from 500,000 to 900,000 ; one-third to onehalf of these were unemployed (SZW 1992). Disability schemes had been widely used to buy off resistance against job restructuring. Under such a scheme redundant workers did not need to re-apply for work, and they received higher and longer-secured benefits. Under the new system benefits are lower; new claimants and recipients under 50 years of age must undergo regular medical examination, and are obliged to accept suitable jobs even at lower levels of pay. This has caused a sharp fall in the number of beneficiaries, from a peak of 925,000 in 1994 to 841,000 in 1995 and to under 800,000 in 1996. Roughly half the claimants under 35 years of age who are re-examined are now disqualified or have their benefits lowered (SZW 1996a). Broad unemployment, as defined above, has fallen, slowly, to 21 per cent in 1996.

In sum, the labour market performance of the Netherlands shows strong and weak elements: strong job growth, a fall in the standardized unemployment rate as defined by the OECD to almost half the current level in the EU; but also a high level of structural unemployment and sharp disadvantages for unskilled and non-native workers. That most newly created jobs are parttime may be seen as a second-best outcome: the expansion of part-time work has helped to attenuate the social division between fully employed and fully unemployed people. A survey in 1993 showed that 15 per cent of part-time workers would have preferred but were unable to find full-time jobs; however, a similar proportion of full-time workers, both men and women, would prefer a four-day working week (OSA 1993). 


\section{British Journal of Industrial Relations}

\section{Three policy shifts}

Three main policy changes have supported the high rate of job growth. The first - in importance and timing — is wage moderation, which was adopted in 1982. The real exchange rate has decreased, by 17 per cent since 1982 compared with other OECD countries (OECD 1995; DIW 1997: 260), helping to make Dutch firms and products more competitive abroad. Negotiated wage restraint entailed two exchanges: first, unions and employers have traded lower wage demands against a reduction in the working week; second, unions and employers have together traded wage moderation against lower taxes and social charges. With the passing of time there was a shift from the first to the second exchange, made possible by the improved public finances and the broader tax base which results from the creation of more jobs.

The second policy shift refers to the reform of the social security system. Initially, the government's objective was to contain costs and reduce the deficit in government spending, which had risen to a staggering 10 per cent in 1982. In the early 1990s the deficit was brought down to under 6 per cent, and in 1996 the 3 per cent EMU target rate was reached. This was implemented in a slow, step-by-step programme, initially through a small decline in public employment and a brake on the salaries of public servants. Beginning with the halt in social benefits in 1983 and an overhaul of unemployment insurance in 1987, the major welfare reforms took place in the early 1990s with the tightening of the two main exit routes from the labour market: disability insurance and early retirement. While wage moderation was adopted by the unions as their dominant strategy, these reforms took place against their opposition.

The third policy shift concerns the innovation of labour market policies and the emphasis on activating measures of various kinds, targeted particularly at the core of the younger long-term unemployed. This is combined with further reforms in social security, and with the removal of disincentives to offer and accept low paid employment. A series of special employment programmes have been introduced. The two most innovative ones are the creation of 40,000 new jobs in the public sector for young unemployed people who have been out of a job for 12 months, and the creation of 20,000 jobs in the private sector for those who have been without a job for six months, with a DFL18,000 subsidy to employers who undertake to provide training and create permanent jobs. Further conditions are that these jobs are for 32 hours per week, and that wages are lower than $120 \%$ of the statutory minimum wage.

\section{Industrial relations}

The legal and institutional framework of Dutch industrial relations was put in place in the 1920s and 1930s. In response to the recessions of the interwar years, the collective agreement received public protection as an instrument against unfettered wage competition. After 1945 the role of the state expanded, and for two decades - longer than in any other Western democracy - the 
Netherlands maintained a statutory wage policy (Windmuller 1969). Implementation of that policy was engineered in close co-operation with the central union and employers' federations, through the Stichting van de Arbeid (StAr), the bipartite Foundation of Labour in which unions and employers have been meeting since 1945, and the Sociaal-Economische Raad (SER), the government's main advisory council in matters of social and economic policy since its legal establishment in 1950.

The government-controlled policy of wage restraint did not survive the opening of the economy following membership of the EEC in 1958 and the Kennedy rounds of the early 1960s. However, attempts to reorganize wage bargaining on a voluntary, bipartite basis proved difficult, and under the new Wage Act of 1970 the government retained the power to impose a standstill on negotiations or to suspend contracts. These powers were used seven times between 1973 and 1982, although new governments usually started with a pledge to observe voluntary incomes policies. Only one central agreement, in 1972, was ever reached, but it had no lasting impact.

The return to voluntary wage moderation took place only in the 1980s and has continued since. Its starting point was the 1982 accord of Wassenaar, socalled after the residential suburb of The Hague where the deal was negotiated. This accord - a pledge of the central organizations to start negotiations in sectors and companies over a wage standstill in exchange for shorter working hours - allowed the government to take its place behind the curtains rather than to be a leading actor. This retreat was sealed with the new Wage Act of 1988, which limits the possibility of direct state intervention in collective bargaining to extreme conditions of economic decline. However, I shall argue that the government still has various instruments with which to cast a 'shadow of hierarchy' (Scharpf 1993) over the bargaining table.

Continuing a policy of wage restraint, the central organizations of unions and employers, in a new accord of December 1993, decided to encourage steps towards decentralized bargaining. While fifteen years earlier it had been possible to evaluate the content of collective agreements on the basis of a few leading ones (e.g. metal manufacturing, Philips, construction), since they all copied each other, this was no longer the case. Moreover, many agreements are now concluded for two, three or sometimes even four years, upsetting any common timing in the negotiations. Yet, research shows that there remain various horizontal and vertical ties between the 5000 or so negotiators who bargain the 720 collective agreements (van der Toren 1996). Before any actual bargaining, there is what Walton and McKersie (1965) call a great deal of 'attitudinal structuring', starting with the drafting of proposals during the summer, then the discussions in the StAr with the government over the budget, presented in September, then lengthy discussions and quasi-negotiations in the StAr and the SER, as well as another meeting with the government in the autumn, a redrafting of proposals in sectoral forums and, finally, the actual negotiations early in the new year. The distance between negotiators physically, socially and since the 1980s also ideologically — is small.

Coverage and scope of collective bargaining have increased. Now, 79 per 


\section{6}

cent of private-sector employees are covered by collective agreements (survey data, Venema et al. 1996), which is many times in excess of union density. Since 1980 coverage has risen against the falling trend in union density - from 35 to 25 per cent in the 1980s but edging back up to 29 per cent in 1996. The scope of collective agreements has widened, and more issues, related to training, special rights for disadvantaged groups and the reinsurance of statutory rights and entitlements that were lowered in recent welfare reforms, are now dealt with in collective bargaining.

The sectoral level has remained dominant: 200 multi-employer agreements cover 65 per cent of all workers; 520 company agreements apply to 14 per cent. This distribution has hardly changed in the past 15 years. There are no examples of large sectoral agreements that have been terminated, and sectoral agreements have remained the norm in most manufacturing industries (except chemicals), in construction, road haulage, commerce, banking, insurance, hospitals and the public sector. Multinational firms (Philips, Shell, Unilever, AKZO-Nobel, Heineken, etc.) have traditionally negotiated their own collective agreements, many of which are as large as sectoral agreements and of a multi-establishment character.

As a rule, collective agreements contain a peace clause and strikes are in breach of contract during their currency. While the right to strike is not otherwise regulated by law, the courts have tended to accept its legality if it is used as a means of last resort when contracts have expired and efforts to renegotiate a new contract have failed. In the past 15 years, in line with international trends, strike levels have fallen, and the Netherlands continues to be placed near the bottom of the international strike league, just above Austria and Switzerland.

Dutch workers have two channels of representation: mandatory works councils, and union membership. Under the Works Council Act of 1979 (most recently changed in 1997), workers in the private and public sectors in establishments with 35 or more staff are entitled to elect a works council. These councils have co-decision rights regarding many HRM issues and must be consulted with respect to major decisions concerning investment, relocation, take-overs, mergers and restructuring. Councils have a monitoring task with respect to the application of collective agreements. They cannot call strikes or renegotiate matters dealt with in agreements, and they generally stay away from pay bargaining. In recent years Dutch works councils have become more involved in consultation over working hours and company restructuring (Visser 1995). However, employers are reluctant to involve works councils in collective bargaining over pay (Teulings 1996). The effective function of councils is probably facilitated by sectoral or company bargaining away from the plant, which removes distributive conflicts from the negotiating table of councils and enhances their capacity for co-operative solutions.

There is no exclusive jurisdiction in the Netherlands, and in nearly all bargaining domains there are two or more unions. The 1927 Collective Bargaining Act leaves employers free to decide whether and with whom they will bargain; if they conclude an agreement with any particular union, its terms 
apply to members of other unions and non-members in the same domain. This implies that unions are always faced with the threat of exclusion, something that happens just often enough to be real. In the absence of a legal right of recognition for unions, and given the threat of exclusion, coalition building is the only remedy. Since only signatory unions are bound by a peace clause, employers are normally keen to involve all unions with significant membership. Unions prefer not to stand aside, because only signatory unions gain the union representation rights established through collective bargaining, and only they receive the annual employers' fee in compensation for the erga omnes application of agreements.

These rules of the game explain why all collective bargaining takes place at a single table. This configuration has an in-built bias towards the moderation of demands, since the most radical party on either side, the one whose initial position deviates most strongly, runs the largest risk of exclusion (Rojer 1996). Exclusion has in recent years affected the largest unions at Philips (in 1996), Heineken (in 1995) and the Dutch railways (in 1995), and it nearly always affects the union or unions with the most radical demands regarding the reduction of working time.

The 1937 Law on Extension and Nullification of Collective Agreements allows the minister of social affairs and employment to extend the collective agreement to employers who are not members of the signatory employer association(s), if the agreement covers a substantial majority of the industry. In actual practice, this is interpreted as a 55 per cent coverage rate. Extension does not affect companies that have negotiated a company agreement. Until recently, extension has been a routine affair, covering 19 per cent of firms and 6 per cent of private-sector employees. Since 1994 the minister has used the possibility of not extending agreements as a stick to obtain certain policy objectives, in particular the creation of entry wage scales (near the minimum) for workers with little training and few skills. This particular shadow of hierarchy appears to have worked well, and in two-thirds of all agreements negotiated in 1995 new entry wage levels have been inserted (Venema et al. 1996). Employers and unions evidently value the legal extension of agreements as a means to maintain collective organization.

The possibility of extension gives firms an incentive to join and helps to explain the high level of collective organization among Dutch employers. Membership of employers' associations is virtually complete among firms with 100 or more workers, including all major multinational and many foreign firms, but density is lower in the small-firm sector. Overall, the density of employers' associations, measured in terms of workers employed in organized firms, lies in the $70-80$ per cent range and is stable.

Since the recent merger between Christian and general employers' associations, the organizational landscape has become rather more simple. VNO-NCW is the peak association for large employers in industry and services; MKB-Nederland represents small and medium-sized firms; and LTO-Nederland organizes agricultural interests. Each represents the employer and trade interests of their members. VNO-NCW has about 130 affiliates 
representing entire sectors such as metal engineering, textiles, construction and banking, but has a tradition of direct involvement of the major multinational firms in its governing body. One of the largest affiliates, the General Employers' Association (AWVN), organizes throughout industry and services, and is involved in an advisory role, in three-quarters of all company agreements. Until 1993, the VNO maintained a central joint resistance fund in order to bolster internal discipline, and employers have jointly upheld a veto against general rounds of reduction in working time.

The legal setup of collective bargaining is more ambiguous for the unions. It institutionalizes pluralism, encourages coalition building and discourages open conflict. The practice of public protection of collective agreements helps to prevent the emergence of a non-union sector based on low wages and Schmutzkonkurrenz, which would otherwise be possible in the absence of recognition requirements on employers. On the other hand, it removes incentives for workers to join (Klandermans and Visser 1995).

Low membership levels and internal divisions are the weak points of Dutch trade unions. Unions lost about one-sixth of their members in the early 1980s but made a strong recovery by the end of the decade and since. About one-fifth of all union members are retired from the labour force. Union density rates vary across sectors; the highest rates are in construction ( 43 per cent), transport and communication (42 per cent), education (39 per cent) and public administration ( 37 per cent), falling to 32 per cent in manufacturing. Density has risen from 10 to 25 per cent in banking, but has remained around 5 per cent in business and personal services. The male-female difference has narrowed, but at 20 per cent the female density rate is still much lower than the male rate (34 per cent). Among part-time workers (20-34 hours), density is 23 per cent, compared with 13 per cent of those working between 12 and 19 hours, and 31 per cent of full-time workers (Klandermans and Visser 1995; van Rij 1997).

There are three main peak federations, of which the Federation of Dutch Trade Unions (FNV), with 1.2 million members or 62 per cent of all union members in the country in 1996, is the most important. FNV was formed between 1976 and 1982 through a merger of the Social Democratic and Catholic unions. Its largest affiliate in the private sector, the Industries' Union (IB), organizes in almost all manufacturing industries and is involved in 30 or more sectoral and 150 company agreements. The co-ordinating abilities of this union are helped by the fact that it maintains a strong central strike fund which is used to prevent large wage differences across sectors and firms. The largest FNV affiliate is the Public Employees' Union, which negotiates the eight sectoral agreements in the government sector, the major national agreements in the health service and numerous company agreements in privatized firms, such as the PTT or utilities.

The Christian-National Union Confederation (CNV) has around 350,000 members and is the second largest federation. Its structure mirrors that of the FNV, of which it is nearly always the junior partner. The majority of its membership is in the public sector. The Federation of White-Collar and Senior Staff (VHP) organizes occupational and company unions in most large firms 
and in the public sector, and is about half the size of the CNV. Around 10 per cent of all union members are organized in unaffiliated unions, mainly in public services, nursing, teaching and transport.

Unions co-operate in collective bargaining and through the joint membership of works councils. They also participate in numerous advisory and consultation boards, for instance in the national and regional Manpower Services Boards. For the purpose of wage bargaining, the two most important are the already mentioned Foundation of Labour (StAr) and the Social -Economic Council (SER). StAr is co-chaired by the presidents of the FNV and $\mathrm{VNO}-\mathrm{NCW}$ and is the forum where the various central accords of recent years have been negotiated. Smaller, but basically with the same union and employer representatives, StAr is housed in the building of the SER. This body also includes 11 government-appointed experts, including the president of the Dutch Central Bank and the director of the Central Planning Bureau, the government's forecasting institute. Once the 'apex' of corporatism and elite co-operation (Lijphart 1968), the SER saw its capacity to offer unanimous advice and influence government policy decline during the 1970s and 1980s (Klamer 1990). Parliament in 1995 abolished the council's prerogative to be consulted over new social and economic legislation, but it appears that this has shocked the council into new activity, and the SER has produced more unanimous advice in the 1990s than in preceding decades.

\section{Implementation and consequences of wage moderation}

\section{The Wassenaar Accord}

Voluntary wage moderation started in 1982, when Dutch unions, impressed by soaring unemployment and rapidly falling membership, convinced themselves that improving the profitability of Dutch industry was a sine qua non for any strategy of recovery. Unions lifted their veto against the suspension of the automatic cost-of-living escalators and employers withdrew their ban on negotiations of a working week of under forty hours.

More than a resignation to the fact of economic hard times, the Wassenaar accord marked the victory of the moderate faction within the FNV, led by the Industries' Union (IB). Four years earlier, shocked by severe job and membership losses in shipbuilding and other metal manufacturing, IB had reversed its radical stance on income redistribution and power sharing, and adopted a policy of wage moderation and working-time reduction. In 1979 IB gained the support of the federation, but a central agreement along these lines failed because of the implacable opposition of some FNV affiliates. The sharp and seemingly unstoppable rise in unemployment in the early 1980s produced a change of mood. At first employers had little enthusiasm for a central agreement; union bargaining power was no longer seen as a problem, and they disliked the reduction of the working week which the unions sought as part of the deal. However, employers appear to have changed their mind when the 
incoming centre-right Dutch government intimated that it might copy the French or Belgian example and impose a reduction of working hours in compensation for wage restraint.

In the Wassenaar accord, negotiators of sectoral and company agreements were advised to suspend the payment of cost-of-living adjustments in favour of a cost-neutral introduction of shorter working hours. In consequence escalator clauses, widely introduced in the late 1960s, disappeared almost overnight and real wages and wage costs fell sharply. Average real wages fell by 9 per cent, the largest drop since the Korea crisis (van Zanden and Griffiths 1988). A 5 per cent reduction in the working week, from 40 to 38 hours, was implemented between 1983 and 1986, mainly through extra holidays. The immediate impact of the accord was that it restored profitability in the private sector. The share of income imputed to labour had risen to an unprecedented 91 per cent in 1980, but dropped to 81 per cent in the course of few years and has since undulated around 83 per cent.

\section{Minimum Wages, Social Security and Public-Sector Pay}

The 1982 accord eased the position of the new centre-right government, led by Ruud Lubbers of the Christian-Democratic Party, in coalition with the Liberal Party. This government had announced a 'no nonsense' policy of recovery of private-sector profits, reduction of public expenditure and full employment - in that order. The decision of the unions to accept falling real wages made the government's decision to reduce public-sector pay and social benefits seem 'less unfair' and 'easier to sell' (Wellink 1987: 359).

One of the first decisions of the Lubbers government was to freeze civil servants' salaries, the statutory minimum wage and social benefits for the year 1983. For 1984 the government announced a 3.5 per cent reduction in salaries, wages and benefits. Predictably, this brought the public-sector unions up in arms; they organized their largest ever postwar strike, only to discover that they were isolated. When an increasingly hostile public turned against them, the unions were quick to cite the avalanche of civil court orders requiring them to end the strike.

Just as Wassenaar marked the beginning of the return to voluntary wage bargaining in the private sector, the government's victory, paradoxically, was the beginning of the end of its unilateral power in public-sector wagesetting. Since 1903 there had been a ban on public-sector strikes, and from 1962 onwards public servants' salaries had been set by the government, on the basis of developments in contractual wages in the private sector. The statutory minimum wage, introduced in 1969, was also indexed to contractual wages, and serves as the anchor for all social benefits, the lowest level of which is 70 per cent for a single person, moving to 100 per cent for persons with family responsibilities. The combination of this system of pay linking, automatic price escalators and a growing volume of public employment and social benefits came to be an ever increasing squeeze on the budgetary autonomy of governments. By the end of the 1970s, 60 per cent of the annual 
budget was determined by the outcome of annual wage negotiations and no government could afford not to be interested in its outcome (Albeda 1987).

In the 1983 dispute, the courts, citing the European Social Charter, which the Netherlands had ratified only in 1980, threw out the 1903 ban on striking by public employees. In effect, the judges sent the unions and the government to the bargaining table. The actual cut in pay became 3 per cent, and the pill was sweetened by a reduction in the working week of government employees to 38 hours, taking effect in 1987. On average, public-sector pay fell behind, approximately by 10 per cent between 1982 and 1990 relative to private-sector wages. The minimum wage and statutory benefits remained frozen until 1990 and fell behind by 15 per cent in the same period, by 20 per cent until 1996. In 1990, with the entry of the Party of Labour in the third Lubbers government after two centre-right governments, the linking of the minimum wage and social benefits contractual wage developments in the private sector was restored; it was suspended again three years later, and restored again in 1996 and 1997. Labour relations in the public sector have gradually been privatized; while civil servants lost most of their special privileges with respect to pensions and dismissal protection, civil servants' unions gained the right to strike and to bargain collectively. This process was completed in 1993 with the introduction of eight sectoral bargaining jurisdictions (e.g. central government, local government, police, education and so on).

\section{The 'New Direction' Accord of 1993}

After 1986 the movement towards shorter working hours stalled. Between 1983 and 1986, a reduction in working time had taken place in the context of massive labour shedding in an effort to save existing jobs. It is estimated that 25-40 per cent of the reduction of working time in the private sector has been achieved through jobs lost and the remainder through increased labour productivity and work intensity (CPB 1987). When the economy moved out of the recession, the unions geared up for another round of working time reduction - to 36 hours - still without pay compensation, in an attempt to create new jobs. But employers declared any general reduction to fewer than 38 hours off-limits. The unions were divided; the VHP unions abandoned the FNV-led coalition for shorter hours, and the FNV public servants' union made the recovery of the wage decline of the early 1980s its priority. By 1987, the campaign for shorter working hours was dead and the will to continue wage restraint seemed exhausted (Visser 1989). The international economic boom between 1988 and 1991 encouraged unions to raise their aspirations, and renewed membership growth helped to restore confidence.

A small wage rise was achieved, but the party was over almost before it began. In 1992 the economy moved into recession, and a number of major firms, such as electronics producer Philips, aircraft manufacturer Fokker and Daf-trucs, were in trouble: 100,000 jobs in manufacturing, 10 per cent of 
the total, were shed between 1992 and 1994. In the autumn of 1992 the government threatened a wage freeze, although it is doubtful whether there was any legal basis for such action. However, it had sufficient other sticks, especially a parliamentary majority in favour of the curtailment of employer and union influence in the administration of social security, to make this particular shadow of hierarchy work. In the final days of 1992, the central organizations of unions and employers recommended a breathing space of two months during which the new facts of international recession were allowed to be absorbed by lower-level negotiators. Employers began a campaign for zero wage increases, and unions lowered their wage demands and many negotiated multi-annual agreements in which nominal wage increases would not keep pace with price inflation (Figure 2).

In December 1993 the return to wage moderation was confirmed in a new central accord, called 'New Direction', which recommended a more decentralized model of implementing central guidelines. The impact of this accord has been no less than the one of 11 years before. Unit labour costs fell by 6 per cent (Figure 2). Employers lifted their veto against a further reduction of working hours, and the issue reappeared on the bargaining agenda in 1995 and 1996. In a number of sectors and companies, experiments with shorter hours have started, introducing corridors of 32-40 weekly hours, relaxing constraints on unsocial hours and introducing lower overtime rates or compensation by time off rather than extra pay. About half of all full-time employees covered by collective agreements have now a working week averaging between 36 and 37 hours.

\section{'Wassenaar' and 'New Direction' Compared}

Comparing the two accords, there are some obvious similarities and differences. Both were concluded under the impact of a recession and job losses, and were concentrated in industry and in the export sector. Both accords were negotiated under a shadow of hierarchy, and in both cases employers were probably most moved by the threat of government legislation imposing obligations on them. In 1993 employers wanted to safeguard bipartism. Only three years earlier, in 1990, the central employers' federations had withdrawn from a vague tripartite 'Common Policy Orientation' pact. This pact had been negotiated in 1989, but with the entry of the Party of Labour into the government employers feared that it might be used as a ploy 'to bring the state back in'.

The differences between the two accords lie in both content and form. In 1982 the emphasis was on the restoration of profits as a condition for job creation, and on the redistribution of jobs to halt the rise in unemployment. In 1993 job creation and job redistribution remained the prime objectives for the unions, but the containment of labour costs was combined with a cautious support for expanding domestic demand, made possible by low inflation, a large trade surplus, a strong currency and improved public finances. The 1993 accord marked the transition to a new type of exchange, 
FIGURE 2

Contractual Wages, Inflation and Unit Labour Costs, 1982-1995 Source: CBS
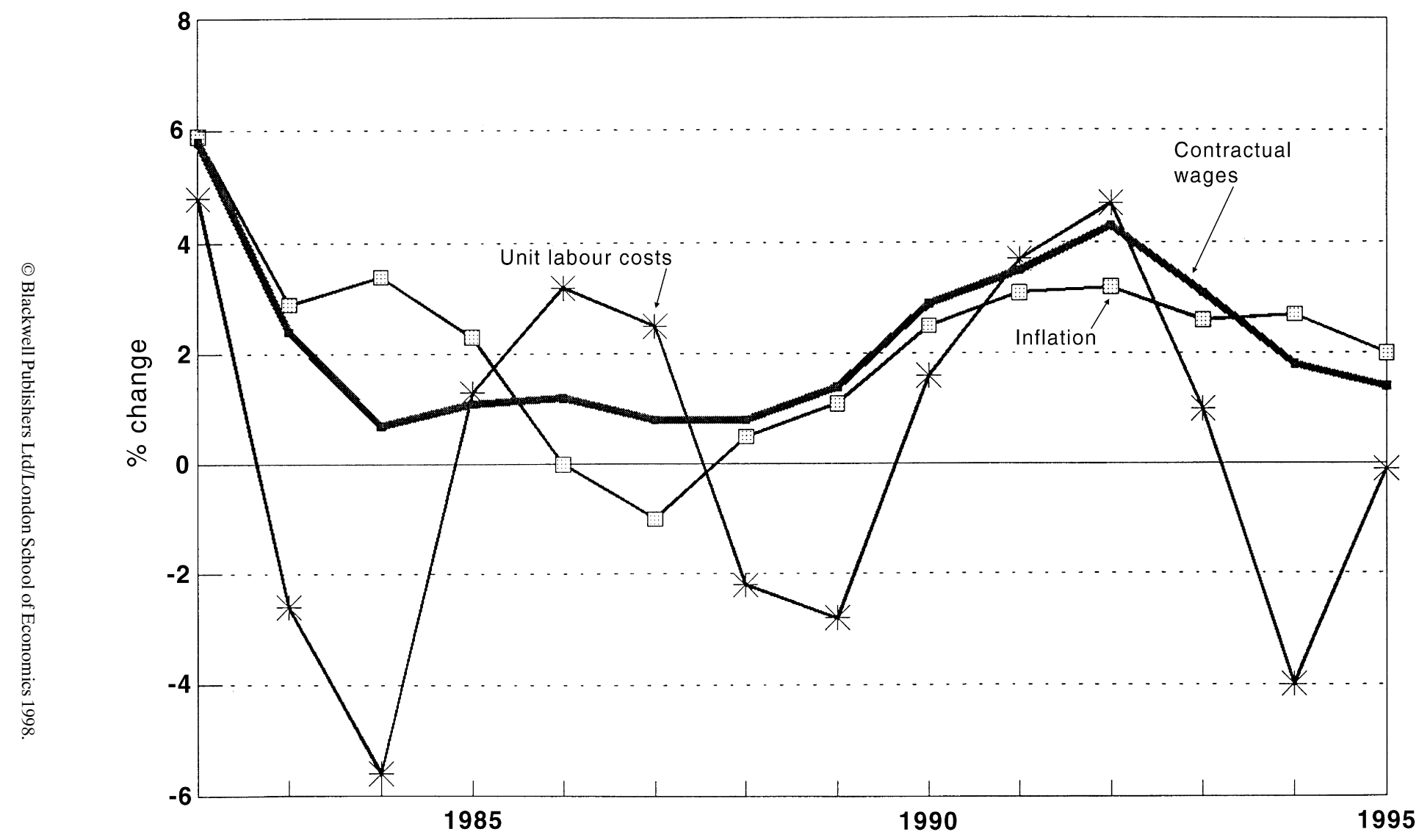
between wage moderation and fiscal compensation, setting in motion a virtuous circle of more jobs, lower per capita taxes and hence more spending power, while paying flat wages to those already in employment. Although export-led growth remained important, as it had been in the 1980s, the explanation of the 1990s job creation record is based on domestic-led growth, concentrated in services tied to the local economy. It is this structural change towards an American-type service economy, accelerated by wage moderation, fiscal compensation and job redistribution, that has allowed the Netherlands to be relatively unaffected by the recession in Germany and other European economies (see Table 1).

TABLE 1

Economic Performance, Netherlands and the European Union, 1991-1996 (\%)

\begin{tabular}{lcr}
\hline & Netherlands & \multicolumn{1}{c}{$E U$} \\
\hline GDP & 2.2 & 1.5 \\
Private consumption & 2.3 & 1.5 \\
Investment & 1.3 & -0.2 \\
Employment & 1.5 & -0.5 \\
\hline
\end{tabular}

Source: DNB (Dutch Central Bank), Annual Report 1996, Amsterdam, 1997.

The 1993 accord is a further step in the process of organized decentralization of Dutch industrial relations. Wassenaar led the return to bipartite wage bargaining; New Direction, coming after the trust-building experience of 11 years, promised a further step towards decentralization, with increased involvement of local bargainers.

\section{Evaluation of Wage Moderation}

According to the Central Planning Bureau, wage moderation has been 'Holland's single most important weapon in international competition' (CPB 1995: 268). The effect of lower labour costs appears to have dominated the effect of lower aggregate demand. For the second half of the 1980s, the Bureau estimates that two-thirds of job growth can be attributed to wage moderation and one-third to the expansion of the world economy. The Department of Social Affairs and Employment estimates wage moderation at 1.2 per cent lower wage increases per year between 1983 and 1989 , to which it attributes about half of the net gain of 700,000 jobs in these years (SZW 1990). Table 2 demonstrates that labour costs increased less than in partner countries, especially when account is taken of labour productivity and when unit labour costs are compared.

The Netherlands has experienced a more labour-intensive growth pattern than Belgium or Germany, contradicting the dire predictions of 'jobless growth'. In spite of the revaluation of the guilder by about 13 per cent since 1987, the competitive position of Dutch firms has not deteriorated, in 
TABLE 2

Labour Costs in Manufacturing: Changes 1980-1994 and levels of 1994*

\begin{tabular}{lrrrrrrr}
\hline & $\begin{array}{c}(1) \\
\%\end{array}$ & $\begin{array}{c}(2) \\
\%\end{array}$ & $\begin{array}{r}(3) \\
\%\end{array}$ & $\begin{array}{c}(4) \\
D M\end{array}$ & $\begin{array}{c}(5) \\
\%\end{array}$ & $(6)$ & $(7)$ \\
\hline $\mathrm{NL}$ & 31.3 & 19.8 & 57.5 & 34,87 & 80 & 79 & 89 \\
$\mathrm{~B}$ & 24.3 & 28.1 & 59.2 & 37,35 & 94 & 85 & 90 \\
$\mathrm{D}$ & 54.9 & 30.6 & 102.4 & 43,97 & 82 & 100 & 100 \\
DK & 40.9 & 19.5 & 68.4 & 34,41 & 22 & 78 & 93 \\
GB & 61.4 & 13.4 & 63.1 & 22,06 & 40 & 50 & 106 \\
$\mathrm{~S}$ & 43.9 & -6.8 & 34.1 & 31,00 & 70 & 71 & 94 \\
J & 144.0 & 19.8 & 253.8 & 36,01 & 69 & 82 & 81 \\
USA & 59.1 & 5.8 & 68.3 & 27,97 & 43 & 64 & 99 \\
\hline
\end{tabular}

* NL $=$ Netherlands; $\mathrm{B}=$ Belgium; $\mathrm{D}=$ Germany; DK $=$ Denmark $; \mathrm{GB}=$ Great Britain $; \mathrm{S}=$ Sweden; $\mathrm{J}=$ Japan

(1) \% change in labour costs per hour worked in manufacturing, 1980-89, in DM

(2) \% change in labour costs per hour worked in manufacturing, 1989-94, in DM

(3) \% change in labour costs per hour worked in manufacturing, 1980-94, in DM

(4) total labour costs per hour worked in manufacturing in 1994

(5) indirect labour costs as a percentage of direct labour costs

(6) index of total labour costs per hour worked in manufacturing (see (4)): Germany (D) $=100$

(7) index of total labour costs per unit produced in manufacturing: Germany (D) $=100$.

Source: SZW (1996b, based on tables 2.1-2.3).

contrast to German firms in the 1990s. Employment growth was 1.5 per cent from 1991 to 1996; in Germany, including the new east German states, it was 0.2 per cent (DNB 1997). According to a study of the Belgian Kredietbank, economic output increased by 80 per cent since 1970 in both countries; in the Netherlands this has resulted in 19.6 per cent more jobs since 1983; in Belgium, in just 4.6 per cent.

Yet some economists express doubts concerning the wisdom of wage moderation. The Deutsches Institut für Wirtschaftsforschung points out that, over the full period from 1982 to 1996, GDP growth was only marginally higher in the Netherlands (44 per cent) than in West Germany (39 per cent). In the Netherlands job growth was more than twice as large (18 per cent compared with 7 per cent), but this combines with lower productivity growth, measured per capita, in the Netherlands ( 20 per cent) than in West Germany (27 per cent) (DIW 1997). The Berlin-based institute argues that wage moderation, like working-time reduction, is not a wealth-promoting but a distributive policy which may lead to impoverishment. In this connection, attention is drawn to the fact that the Netherlands, ranked by GNP per capita, has declined from the top five to the middle range of EU countries. 
Another criticism is that wage moderation is counterproductive in the long run, because it prevents 'creative destruction' in the Schumpeterian sense and keeps lazy entrepreneurs in business. The decline in expenditure on $\mathrm{R} \& \mathrm{D}$, expressed as a proportion of GDP, is cited as an illustration (Kleinknecht 1996). The jury is still out as to whether there is a connection, and these critiques tend to overlook the fact that the Netherlands has become a service economy, with productivity growth and $R \& D$ expenditure rates that cannot be compared with a manufacturing-based economy. Structurally, the Netherlands compares better with the USA than with Germany.

I have suggested above that in times of mass unemployment the redistribution between full-time and part-time jobs may be a second-best solution. From a dynamic perspective, the question is whether this solution institutionalizes a situation of underemployment and marginal jobs for some, or holds the promise of a new model of employment for all, but on a part-time basis, employment that is less gendered than past divisions between work and family responsibilities. I cannot deal with this question here (see Delsen 1997).

Wage moderation must also be evaluated from a dynamic perspective. Under conditions of large-scale unemployment, structural change towards a service economy and the disappearance of low-skilled jobs in manufacturing industries, it offers a solidaristic union strategy because it helps to produce more jobs than any alternative policy prescription if a lowering of wages and social security to below the poverty line is rejected and a Keynesian policy of demand expansion is ruled out, as was the case (for obvious reasons) in the Netherlands in the 1980s and 1990s. This does not imply that it is a sufficient instrument: persistent structural unemployment shows that it is not. Other measures, ranging from social security reform to activating manpower policies, cannot be avoided. However, these painful reforms can be expected to meet with less resistance under conditions of strong job growth.

Many foreign commentators highlight the extraordinary consensual nature of Dutch industrial relations and contrast this with the opposition of French, Belgian or German unions to reforms and budget restrictions in the run-up to EMU. We tend to overlook the fact that the intervention in public-sector salaries (1983), the announcement of reforms in the disability scheme (1991) and the employers' attack on early retirement provisions (1995) led to the largest strikes and demonstrations of the entire postwar period (van der Meer 1996). The unions wanted but were unable - perhaps insufficiently united and motivated - to stop the social security reforms. The parties of Mr Lubbers (Christian Democrats) and Mr Kok (Social Democrats), responsible for the most painful intervention in disability and sickness insurance, lost the general elections of 1994, and it was only because his party remained largest that former FNV chairman, finance minister and Party of Labour leader Wim Kok, became the next prime minister in a coalition with the Liberal and Democratic Parties.

Changes in the Netherlands began 15 years ago with an accord that helped 
to restore job growth. Today Dutch unions do not hide their satisfaction. Whatever defeats they had to swallow, they feel vindicated by a strategy that has gained them members (30 per cent more since 1988, 14 per cent more since 1980). Only a few years ago they found it difficult to justify their policies to European colleagues (interview with Johan Steekelenburg, departing FNV chairman, 20 April 1997).

Does this mean that a wage moderation policy can or should be continued endlessly? Probably not, or not only. There is no point in maintaining wage moderation simply for the sake of low-cost competition in export markets; if your competitors in high-cost economies do the same, stronger medication is needed. The temporary advantage of lower costs is that it gives you a means to increase labour force participation, especially in services, and helps to lower dependency, social charges, taxes and wage costs. This has been the major rationale for wage moderation policies in the Netherlands, and it remains relevant in a context in which broad unemployment affects one in five in the labour force. Another beneficiary of moderation, mentioned in the New Direction accord, is training, including a wider use of sabbaticals and measures to improve employability. Any investment in human capital and in measures making firms less dependent on wage costs and increasing their attachment to the domestic labour market should be welcomed.

\section{Corporatism is dead; long live corporatism!}

In the comparative political economy literature, the Netherlands, with Austria, Sweden and Norway, has been ranked among the elite of corporatist economies, with institutionalized participation of organized interests in the formation and implementation of public policies, centralized and comprehensive organization of workers and employers, and a history of consensual bargaining (Lehmbruch 1982). However, many authors who analysed the 1970s and early 1980s revealed an uneasiness about where to place the Dutch system. The dismal employment performance during these years suggests that corporatism was not a sufficient condition for economic success (Scharpf 1991), that corporatism had destabilized 'from within' (Hemerijck 1993), and that full employment had been replaced by income distribution as the overriding objective of policy-makers (Braun 1988; Therborn 1986). In the domestic debate, corporatism became associated with institutional arthritis - a lack of distance between public and private interests, leading to unclear, costly and slow decision-making. For Wil Albeda, minister of social affairs between 1977 and 1981 and a friend of corporatism, the failure to achieve wage moderation before the unemployment catastrophe of the early 1980s was 'proof of the bankruptcy of the Dutch consultation system' (Albeda 1987: 311). Wim Kok, current prime minister, and at the time chief union negotiator and co-architect of Wassenaar, later admitted that years had been wasted. Earlier attempts, 
especially in 1979, to reach a central agreement had been blocked by Mr Kok's own rank-and-file.

How can we explain the renewal of corporatism? In answering this question, it is important to make an analytical distinction between policy content and institutions. Corporatism is no formula for producing the right answers to new policy challenges. In 1970s, not only the unions but also government parties were internally divided over what would be the right answer to the external shocks of rising energy prices, monetary volatility and, on the domestic front, the rising demands for democratic participation and equality. The internal dispute within the governing Christian Democratic party between a Keynesian and monetarist faction has been documented by Hemerijck (1993). Under such conditions, when there is not yet a political and intellectual winning coalition in favour of a particular causal understanding of the problems and a particular policy prescription, the fact that policy formation and implementation is shared between public and private actors may slow down change even further.

When a new understanding of causes and solutions does emerge and gain the upper hand, corporatism facilitates rapid implementation. Without the Wassenaar accord, price escalators would not have disappeared overnight and the adjustment to the external shock would have been slower. The New Direction accord is another illustration of rapid adjustments. This corresponds with the fact that in international comparisons the Netherlands ranks high on nominal elasticity (the speed with which nominal wages adjust to inflation) and real elasticity (the adjustment of real wages to increases in unemployment) (Layard et al. 1991; SZW 1996b).

Why did the unions support the policy of external adjustment? I think there can be little doubt that soaring unemployment, job losses and membership declines produced the support for wage moderation in 1982 that only a few years before had not been there. However, the survival threat to the unions is not the whole story; it might just as well have pushed them further into a defensive position. My thesis is that the sharp curtailment of union bargaining power within an institutional and political context of unquestioned legitimacy has helped the unions to adapt and refocus their demands to wage moderation and job growth. In this sense, their participation in joint councils with employers and the continuation of public policies supporting sectoral organization and collective bargaining helped (see also Traxler 1996).

Wassenaar was what Saltsjöbaden (in 1938) had been for postwar Swedish labour relations: a reorientation towards a co-ordinated, bipartite and nonstatutory model of negotiating central guidelines for responsible collective bargaining in sectors and firms. It marked the end of the interventionist and tripartite phase in Dutch wage policies, and allowed the government to concentrate on facilitating wage negotiations, rather than prescribing their outcome. By making its budgets less dependent on private-sector wages and by not being party to the negotiations, the government could cast a more effective shadow of hierarchy over the bargaining table. 
Wassenaar has rightly been called the 'mother of all accords' (van Bottenburg 1995). As many as 78 reports, guidelines, joint opinions, reports of advice, recommendations, accords and agreements have followed, on issues varying from the use of alcohol at work, non-Christian public holidays, jobs for ethnic minorities and rights of part-timers, to wage moderation and training targets. Over and beyond its immediate impact on helping the country through difficult times, the accord initiated a new consensual phase in Dutch industrial relations. Following Schmitter (1983), a corporatist bargaining system lies in the fuzzy zone between 'accommodation of interests', in which contracting parties 'agree to some specific distribution of initial contributions and subsequent outcomes', and a 'reconciliation of purposes', in which they 'learn to interpret reality in broadly the same way and to value generally the same thing'. The 1982 accord is a fine example. It set in motion a serendipitous process in which 'social partners', through multiple and protracted exchange, became 'better informed about each other's intentions, respectful of each other's capabilities, and willing to trust each other's commitments'.

The renewal of corporatism in the Netherlands started with a strong signal from the market - in particular, unemployment and the erosion of union bargaining power. In the course of the past 15 years other signals have followed, especially in the domain of social security. The continuation of corporatism can in my view be explained by the trust-generating exchange alluded to by Schmitter, by the resolve of unions and employers to defend their joint institutions, and by the success of the policies these institutions help to select and implement. Trust was evident when employers and unions decided in 1993 to make a further step towards controlled decentralization. The resolve to defend their bipartisanship against government intrusion and market disintegration was demonstrated in 1992, when an interventionist minister of social affairs and employment wanted to dictate bargaining outcomes, and in 1996, when central employers' organizations put pressure on Philips, Unilever and other firms to stay in the fold.

Finally, nothing works like success, and one may doubt whether any party might have chosen a strategy with better pay-offs. In this paper I have tried to show that the corporatist exchange of the past 15 years worked first of all for employers, who recovered from a profitability crisis and improved their competitive position in international markets, and later for unions, which boosted more jobs and members, as well as for the maintenance of vital aspects of the welfare state in spite of retrenchment.

Final version accepted 10 November 1997.

\section{Acknowledgements}

I wish to thank Jeannine Goetschy (CNRS, Paris), Anton Hemerijck (Erasmus University, Rotterdam), Marc van der Meer (University of 
Amsterdam), Joris van Ruysseveldt (Open University, Heerlen), Wiemer Salverda (University of Groningen) and Werner Sengenberger (ILO, Geneva), and the reviewers and the editor of this Journal for their useful comments and critique. Needless to say, remaining errors and the views expressed are my own.

\section{References}

Albeda, W. (1987). 'Loonvorming in de tijd van neergang tot beginnend herstel 1973-1987'. In A. Knoester (ed.), Lessen uit het verleden. 125 jaar Vereniging voor de Staathuishoudkunde. Leiden/Antwerpen: Stenfert Kroese, pp. 305-18.

Beer, Paul de (1996). Het onderste kwart. Werk en werkloosheid aan de onderkant van de arbeidsmarkt. Rijswijk: Sociaal en Cultureel Planbureau.

Bottenburg, M. van (1995). Aan den Arbeid! In de wandelgangen van de Stichting van de Arbeid, 1945-1995. Amsterdam: Bert Bakker.

Braun, D. (1988). 'Die Niederländische Weg in die Massenarbeitslosigkeit (1973-1981): Eine politisch-institutionelle Analyse'. PhD thesis, University of Amsterdam.

CBS (1996). Enquête Beroepsbevolking. The Hague: Central Bureau of Statistics.

CPB (1987). Macro-economishe Verkenningen. The Hague: Central Planning Bureau.

- (1995). Centraal Economisch Plan 1996. The Hague: Central Planning Bureau.

Delsen, L. (1997). 'A New Concept of Full Employment'. Economic and Industrial Democracy, 18(1): 119-36.

DIW (1997). Das niederlandische Beschäftigungsmodel. Berlin: Deutsches Institut für Wirtschaftsforschung, Wochenbericht 1997/16.

DNB (1997). Jaarverslag 1996. Amsterdam: De Nederlandse Bank (Dutch Central Bank).

Hemerijck, A. C. (1993). 'The historical contingencies of Dutch corporatism'. D.Phil. thesis, University of Oxford.

- (1995). 'Corporatist immobility in the Netherlands'. In C. J. Crouch and F. Traxler (eds.), Organised Industrial Relations in Europe: What Future? Aldershot: Avebury, pp. 183-224.

Klamer, A. (1990). Verzuilde dromen: Veertig jaar SER. Amsterdam: Bert Bakker.

Klandermans, P. G. and Visser, J. (eds.) (1995). De vakbeweging na de welvaartsstaat. Assen: van Gorcum.

Kleinknecht, A. (1996). 'Is labour market flexibility harmful to innovation?', Discussion Paper no. 37/6, Tinbergen Institute, Free University, Amsterdam.

Layard, R., Nickel, S. and Jackman, R. (1991). Unemployment: Macroeconomic Performance and the Labour Market. Oxford: Oxford University Press.

Lehmbruch, G. (1982). 'Introduction: Neo-Corporatism in Comparative Perspective'. In G. Lehmbruch and P. C. Schmitter (eds.), Patterns of Corporatist Policy-Making. Beverly Hills and London: Sage, pp. 1-27.

Lijphart, A. (1968). The Politics of Accommodation. Berkeley: University of California Press.

OECD (1993). Employment Outlook 1993. Paris: Organisation for Economic Cooperation and Development.

— (1994). Economic Surveys 1993-1994: Netherlands. Paris: Organisation for Economic Co-operation and Development. 
(1995). Main Economic Indicators 1960-1993. Paris: Organisation for Economic Co-operation and Development.

(1997). Economic Survey of the Netherlands 1996-1997. Paris: Organisation for Economic Co-operation and Development.

OSA (1993). Trendrapport Aambod van arbeid. The Hague, Organisatie voor Strategisch arbeidsmarktonderzoek, report no. 19.

Rij, C. van (1997). 'Leden en arbeidsmarkt: Een statistische verkenning van de FNV in 1996'. CESAR research paper 97/1. Amsterdam: Centre for Research of European Societies and Industrial Relations.

Rojer, M. (1996). CAO-onderhandelingen: een voorspelbaar, logisch en rationeel proces? Amsterdam: Thesis Publishers.

Salverda, W. (1996). 'Is the Dutch economy really short of low-paid jobs?' In C. H. A. Verhaar (ed.), On the Challenge of Unemployment in a Regional Europe. Avebury: Aldershot, pp. 221-40.

Scharpf, F. W. (1991). Crisis and Choice in Social Democracy. Ithaca, NY: Cornell University Press.

(1993). 'Co-ordination in hierarchies and networks'. In F. W. Scharpf (ed.), Games in Hierarchies and Networks: Analytical and Empirical Approaches to the Study of Governance Institutions. Frankfurt a/Main and Boulder, Colo.: Campus and Westview.

Schmitter, P. C. (1983). “"Neo-corporatism”, “consensus”, “governability”, and "democracy" in the management of crisis in contemporary advanced industrialcapitalist societies'. Unpublished paper, European University Institute, Florence.

SZW (1990). Rapportage Arbeidsmarktbeleid 1990. The Hague: Department of Social Affairs and Employment.

— (1992). Sociale Nota 1993. The Hague: Department of Social Affairs and Employment.

- (1996a). Sociale Nota 1997. The Hague: Department of Social Affairs and Employment.

(1996b). De Nederlandse verzorgingsstaat in internationaal en economisch perspectief. The Hague: Department of Social Affairs and Employment.

Teulings, C. N. (1996). De plaats van de vakbeweging in de toekomst. Amsterdam: Welboom.

Therborn, G. (1986). Why Some People Are More Unemployed than Others. London: Verso.

Toren, J. P. van der (1996). Achter gesloten deuren? CAO-overleg in de jaren negentig. Amsterdam: Welboom.

Traxler, F. (1996). 'Collective bargaining and industrial change: a case of disorganisation? A comparative analysis of Eighteen OECD countries'. European Sociological Review, 12: 271-87.

Van der Meer, M. (1996). 'Belangenbehartiging onder druk: de langste bouwstaking na de Tweede Wereldoorlog'. In J. Visser (ed.), De Vakbeweging op de eeuwgrens. Amsterdam: Amsterdam University Press, pp. 118-43.

Venema, P. M., Faas, A. and Samadhan, J. A. (1996). Arbeidsvoorwaardenontwikkeling in 1995. The Hague: Department of Social Affairs and Employment, Labour Inspectorate.

Visser, J. (1989). 'New working time arrangements in the Netherlands'. In A. Gladstone, R. Lansbury, J. Stieber, T. Treu, and M.Weiss (eds.), Current Issues in Labour Relations: An International Perspective. Berlin and New York: de Gruyter, pp. 229-50. 
(1995). 'The Netherlands: from paternalism to representation'. In J. Rogers and W.Streeck (eds.), Works Councils: Consultation, Representation, and Cooperation in Industrial Relations. Chicago: University of Chicago Press, pp. 79-114.

Walton, R. E. and McKersie, R. B. (1965). A Behavioral Theory of Labor Negotiations. Maidenhead: McGraw-Hill.

Wellink, A. H. E. M. (1987). 'De ontwikkeling in de jaren zeventig en tachtig en enkele daaruit te trekken lessen'. In A. Knoester (ed.), Lessen uit het verleden: 125 jaar Vereniging voor de Staathuishoudkunde. Leiden/Antwerpen: Stenfert Kroese, pp. 333-66.

Wijnbergen, S. van (1996). 'Institutionele aspecten van de arbeidsmarktproblematiek in Nederland'. In OSA, Preadviezen over institutionele aspecten van de arbeidsmarkt. The Hague: Organisatie voor Strategisch Arbeidsmarktondrzoek, Working Paper W139, pp. 31-56.

Windmuller, J. P. (1969). Labor Relations in the Netherlands. Ithaca, NY: Cornell University Press.

Zanden, J. L. van and Griffiths, R. T. (1988). Economische geschiedenis van Nederland in de 20e eeuw. Utrecht: Het Spectrum. 